\title{
ENVIGPGIKA
}

Envigogika: Charles University E-journal for Environmental Education ISSN 1802-3061

\section{Otevření ekocentra Dotek}

\section{Jana Dlouhá}

Envigogika 8 (3) - Inspirace (Nerecenzované články)/ Inpiration (Non-reviewed articles)

Publikováno/published 15. 10. 2013

http://dx.doi.org/10.14712/18023061.400

\section{Abstrakt}

Zamyšlení u př́ležitosti slavnostního zahájení provozu Doteku, více než pouhého ekocentra: zcela výjimečného spojení budovy a účelu, lidí a jejich prostředí i naplněných vizí, přírody a kultury; uskutečnění toho všeho ve zcela autentickém, historicky podchyceném $\mathrm{i}$ moderně pojatém kontextu.

\section{Abstract}

Reflections on the occasion of the ceremonial opening of Dotek, which is more than an eco-center: it is quite exceptional combination of building and purpose, people and their environment filled with visions, nature and culture; and making all of this happen in an entirely authentic, historically underpinned and in a modern way designed context.

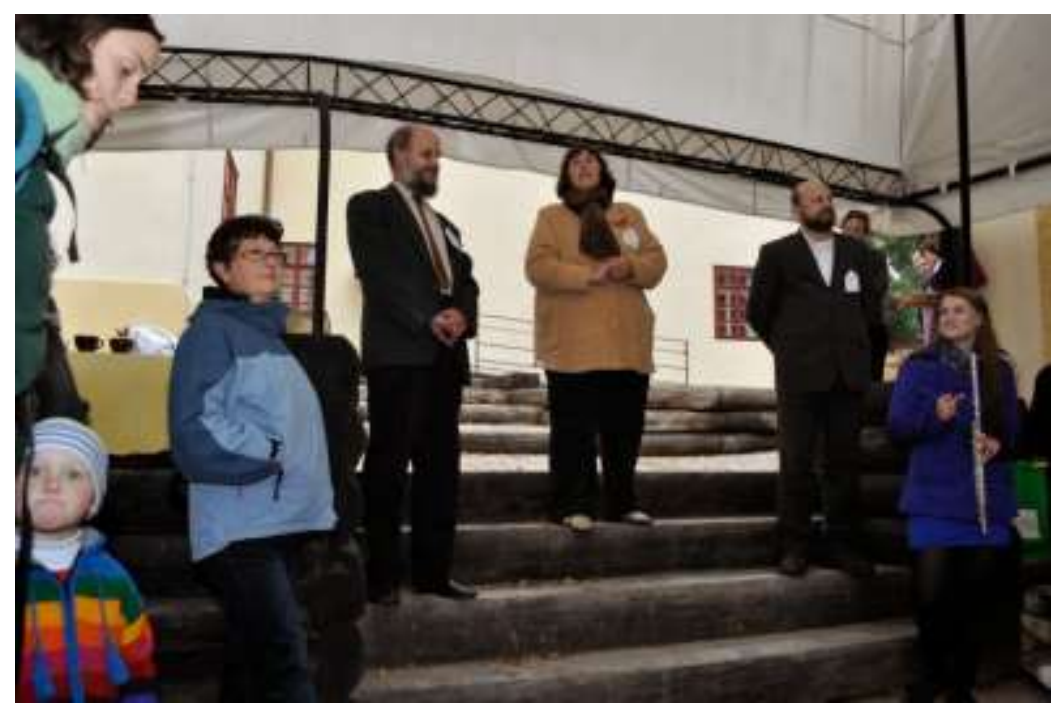


Mezi tragédie tohoto národa patří bezpochyby to, že málokdo dokáže být bohatý. Tedy zbohatnout mnozí umějí, ale uživat si nabytého bohatství tak, aby obohatilo i samotný život, to už není jen tak a rozhodně to nepatři mezi dovednosti, které jsme zdědili nebo se je naučili ve škole. Spiše to vypadá, že si lidé často libují uprostřed četných (nepotřebných) hmotných statků, jejichž nahromaděním si dosvědčují význam a úspěšnost vlastního života. Takové bohatství ovšem radost nepřináší: musí se neustále rozmnožovat, nebot' v okamžiku, kdy je na ústupu, je taky zpochybněno - již neukazuje potenci k růstu, a může tak spíše svědčit o úpadku svého majitele. Se jměním, které slouží jen svému vlastnímu rozvoji, se žije těžko - člověk poměřuje své nerovné síly $s$ jeho mocí, a nevyhnutelně ( $s$ ústupem sil vlastních) nakonec prohrává. To, čeho v lepších časech nabyl, mu pak není ani důstojným pomníkem - zde se totiž hraje jen o budoucnost. $\mathrm{S}$ něčím takovým jako pamět́ se nepočíá a hodnota se nehledá v podstatě; stala se položkou plně relativní, spočívá totiž jen v možnosti navýšení majetku a zisku z toho plynoucím. U statků ležících ladem je tedy velmi sporná.

Tohle mnozí ze současných boháčů tuší spiše intuitivně, a devalvaci se brání velmi primitivními prostředky. Kde má jmění přibývat, je potřeba je stále hromadit, za každou cenu rozmnožovat. Nedopustit ztráty, zavřít za vysoké zdi, opatřit ochrankou, spát $s$ koltem pod polštářem. Co je moje, to se počítá; druhým se dává jen za očekávané protislužby. Tak se z nás stávají rukojmí vlastního hmotného úspěchu, a jsme zbaveni vztahu ke skutečným životním ziskům - co je důležité, je totiž v rukou osudu, který si penězi zcela naklonit nelze (to ale nevíme). A v té abstraktní hře výher či ztrát, kterou s námi bohatství hraje, jsme tak pouhé figury; postupně přicházíme o svou svobodu, i když se všeobecně soudí, že bychom ji právě s jeho pomocí měli nabývat.

Existuje však jiná forma bohatství. Věci, které mají opravdovou cenu, jsou nabídnutou rukou, pozvánkou k dialogu, sdílení času i prostoru. Jsou proudící energií od člověka k člověku, vinou, na které se nesou společné radosti, praání. Lze kolem nich utvářet plány do budoucna, vzpomínat na děje minulé, i jen tak být, právě ted'. Radost je to, co sdílíme - je naplněna, jen když jsme napojeni na něco mimo nás, co přesahuje naše čistě individuální, soukromé potěšení. A vytvářet tuto sdílenou radost, nebo i jen príležitost pro ni, to je umění a vlastně i základ Umění.

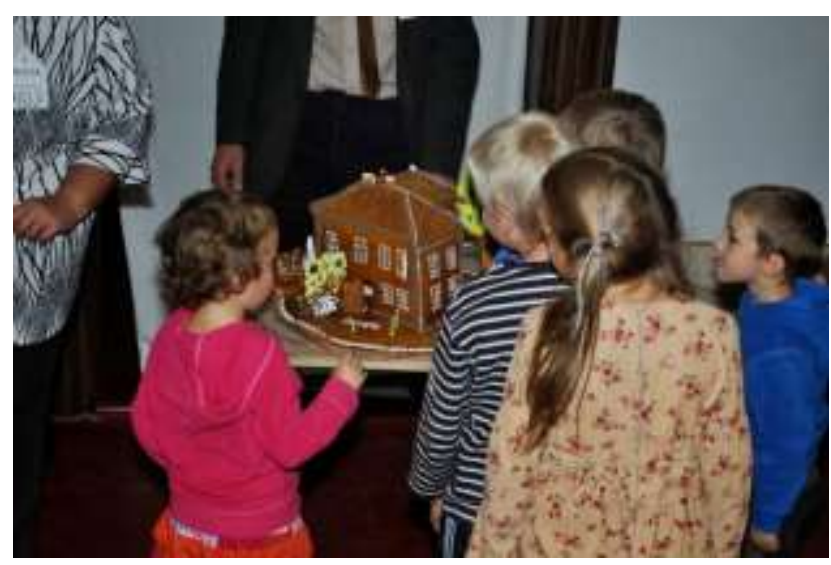

Což se podaří jen nemnohým - těm, kteří dokáží být potichu, naslouchat více, nežli hovořit, dívat se skromně a vůbec vlastní osobu upozadit. Jsou pak odměněni zcela výjimečným propojením se světem věcí i jiných bytostí, a také zvláštní spokojeností, která jako jediná není uspokojením "na úkor" čehosi nebo kohosi. Navíc se stávají "nositeli štafety" - přebírají to, co už bylo předáno jinými, a opět další to převezmou, bez nároku na hmotnou odměnu. Tato štafeta je i historií věcí lidských - jednotlivé její etapy jsou tím, co stojí za zaznamenání. Pamatujeme si přece proto, abychom posílili sebe, podepřeli dobrým příkladem své touhy, sny a vize, které nás vedou životem, na rozdíl od pouhé nutnosti (byt́ zlatě ozdobené). Uchvatitele bohatství a moci si připomínat můžeme sice taky, ale většinou jen jako výstrahu budoucím generacím. 
Tohle všechno platilo kdysi, řeknete si. Dnes je potřeba se prosadit, ukázat, zmocnit se. Získat a pojistit, teprve potom přemýšlet o nějakém rozdávání. Svět je nebezpečný, a tak nás přirozené dobro ohrožuje. Lze ho snadno zesměšnit, nebo dokonce zneužít, a celkově se energie do něj vložená nevyplatí. A přece - existuje, jsou ještě společenství, kde se pěstuje ve své ušlechtilé podobě. Jenom se o tom moc neví, protože se neprosazují, neukazují na odiv.

Jedno z takových míst najdete na SEVERu. O místě samém již bylo napsáno jinde. Také o lidech už psali jiní - obětavých, věnujících své úsilí nikoli soukromým statkům. Pěstujících svébytnou kulturu - pro nás, kteři sem přicházíme, protože je zde př́ijemno pobýt. A jelikož jsme i my př̌šli, viděli a byli zahrnuti do všeobecné př́zně, chceme poděkovat Jirkovi a Haně Kulichovým (a jejich týmu) za to, že si tento prostor nejen vysnili, ale též pro nás otevřeli - našli odvahu a sílu svůj záměr uskutečnit. Obohatilo to možná jejich život (myslím, že spíše ve smyslu nekončících starostí), ale hlavně pak bohatství tohoto místa nabídlo ke sdílení i nám.

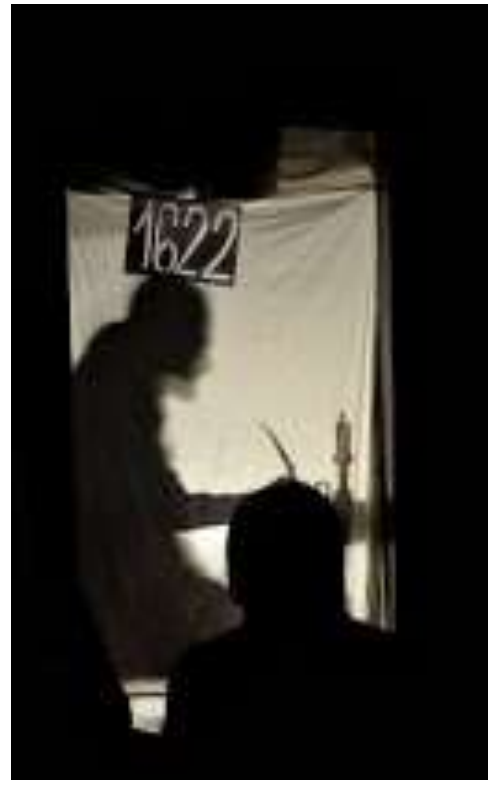

V čem tedy spočivá jeho výjimečnost? Nejspíše $v$ tom, že zde můžeme potkat nejen povrchní krásu věcí a jejich celků - takovou, kterou Ize sledovat v reálném čase -, ale i tu, která vyvěrá z podstaty místa - přichází k nám z minulosti, byla do prostoru a všeho, co jej vymezuje, vdechnuta oněmi minulými "nositeli štafety". Také ovšem místo samé i způsob, jakým je provozováno, je ztělesněním určitého pokroku (my profesionálně postižení bychom řekli udržitelného rozvoje) či poukazem k budoucnosti: takto bychom chtěli, aby ledasjaká budova napříště souzněla s vlastním okolím, našla si svůj účel, zachovala svůj původní charakter a přitom fungovala k nejvyšší spokojenosti těch, co ji užívají, naplňovala jejich nároky. A to se zde plně děje, nejen po stránce technické (o ní ostatně píše Martin Říha), ale především sociální - jedinečné je zejména začlenění do místního kontextu, společenství, kultury. To je možné jen díky otevřenosti, s níž zde vítají návštěvníky, uvádějí je do místních souvislostí, ukazují cestu dál... ale hlavně taky jakési širší otevřenosti, s níž to celé vzniklo: pro radost nás všech.

Tahle otevřenost se projevila v celku i každém, byt́ sebemenším, detailu: na všem je vidět, že láskypIná pozornost byla věnována drobnostem i kontextu, do kterého jsou zasazeny. Najdete zde zátiší připomínající kytice z obrazů Clauda Moneta, zákoutí, která pokazují k tajemstvím minulosti, ale i prostory, kde se plně prosadila moderní architektura pod taktovkou Miloslava Klimeše. Stalo se tak vždy citlivě k původní podobě a určení, a zároveň při plném vědomí svébytnosti, vlastní hodnoty těchto zásahů: daří se jim nejen podtrhnout důstojnost prostoru a jeho prvků, zpř́tomnit ji, ale také ji uchopit nově a jaksi hravě - vznikají tak zcela jedinečné kompozice, které potěší oko i mysl. Hlavním motivem a výrazem těchto úprav jako by bylo bytí člověka - $v$ jeho poněkud transcendentním, mystickém rozměru. Tomu pak zřejmě má podléhat $i$ každodennost $v$ činnostech zde provozovaných, at již jde o přípravu pokrmů a jejich tělesnou konzumaci, nocleh s jeho mocnostmi ovládajícími nevědomí, pohyb v prostoru $\mathrm{s}$ jeho zvláštním rytmem a světelným zarámováním, nebo př́slib událostí v prostorech pro společné dílo a setkávání. Jako by v těchto činnostech byl ukryt hlubší smysl, aniž by vyžadovaly provádění rituálů - a přitom se každá z nich může sama stát projevem vděčnosti za stvoření tohoto krásného místa. 
Jeho krása není pouze vnějším pozlátkem: vyvěrá z hlubšího pochopení dějů, které zde proběhly, i těch, které se teprve uskuteční, odkazuje k naplňování sobě vlastního určení, které souvisí s povahou dobrého lidského společenství a mechanismů, které je utvářejí. Dala by se zde asi vystopovat souvislost "dobrého života" s jakousi časoprostorovou otevřeností: v časovém rozměru se protínající minulostí, přítomností a budoucností, a schopností mezi těmito mody času volně přecházet. Co se týče dimenze prostoru, spočivá v príležitosti $k$ jeho sdílení - nejen při pouhé návštěvě, ale především v přijetí kusu odpovědnosti za jeho osud a ochotě k účasti na jeho poslání, které mu tak zdařile dali do vínku jeho obnovitelé. Otevřenost, zasazena do místa takto „dobrého", nás vede k zamyšlení nad sebou samými a směruje naše snažení; poukazuje ke smyslu skromného, a přitom plného života v rámci společenství druhých lidí.

Dosáhlo se zde několika úrovní propojení: s přírodou, s komunitou. V onom zvláštním propojení s časem, od minulosti do budoucnosti, mưžeme snad pocítit i závan věčnosti - rodí se touha zanechat stopu, naplňuje se vědomí, že by po nás mělo cosi zůstat. Pokud tedy někdo chce, aby jeho život něco znamenal pro druhé, tady je možné najít návod: přijed'te a uvidíte. Rozhodně zde byla štafeta zdárně převzata a jde o to, abychom ji pomohli nést.

Foto Jírí Dlouhý; další obrázky lze nalézt zde

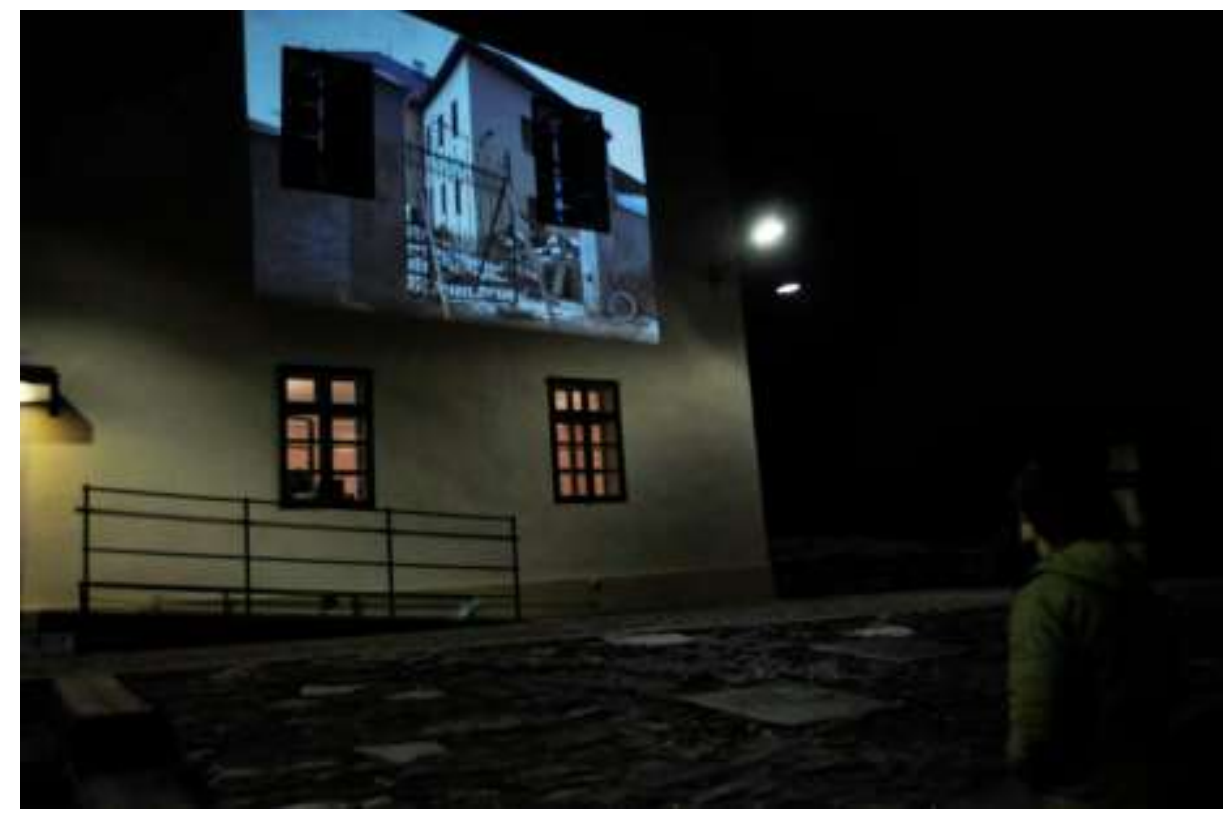

RNDr. Jana Dlouhá, Ph.D.

Centrum pro otázky životního prostředí UK, José Martího 2, 16200 Praha 6, email: jana.dlouha@czp.cuni.cz

Hlavní editor časopisu Envigogika 